This is the authors' accepted version of Dugato, Marco, Francesco Calderoni, and Giulia Berlusconi. 2017. "Forecasting Organized Crime Homicides: Risk Terrain Modeling of Camorra Violence in Naples, Italy." Journal of Interpersonal Violence, June. doi 10.1177/0886260517712275.

Title:

\title{
Forecasting organized crime homicides: \\ Risk Terrain Modeling of Camorra violence in Naples, Italy
}

\author{
Authors \\ Marco Dugato \\ Università Cattolica del Sacro Cuore - Transcrime, Milan, Italy \\ Francesco Calderoni, Phd \\ Università Cattolica del Sacro Cuore - Transcrime, Milan, Italy \\ Giulia Berlusconi, Phd \\ National University of Ireland Maynooth, Maynooth, Ireland
}

\author{
Corresponding author \\ Marco Dugato \\ marco.dugato@unicatt.it \\ +39027234 3715/3716 \\ Università Cattolica del Sacro Cuore - Transcrime \\ Largo Gemelli, 1 \\ 20123 - Milan, Italy
}




\title{
Forecasting organized crime homicides:
}

\section{Risk Terrain Modeling of Camorra violence in Naples, Italy}

\begin{abstract}
Mafia homicides are usually committed for retaliation, economic profit, or rivalry among groups. The variety of possible reasons suggests the inefficacy of a preventive approach. However, like most violent crimes, mafia homicides concentrate in space due to place-specific social and environmental features. Starting from the existing literature, this study applies the Risk Terrain Modeling approach to forecast the Camorra homicides in Naples, Italy. This approach is based on the identification and evaluation of the underlying risk factors able to affect the risk of an homicide. This information is then used to predict the most likely location of future events. The findings of this study demonstrate that past homicides, drug dealing, confiscated assets and rivalries among groups make it possible to predict up to $85 \%$ of 2012 mafia homicides, identifying $11 \%$ of city areas at highest risk. By contrast, variables controlling for the socioeconomic conditions of areas are not significantly related with the risk of homicide. Moreover, this study shows that, even in a restricted space, the same risk factors may combine in different ways, giving rise to areas of equal risk but requiring targeted remedies. These results provide an effective basis for short- and long-term targeted policing strategies against organized crime and gang-related violence. A similar approach may also provide practitioners, policy makers and local administrators in other countries with significant support in understanding and counteracting also other forms of violent behavior by gangs or organized crime groups.
\end{abstract}

\section{Keywords}

Homicide, violence exposure, risk terrain modelling, organised crime, crime forecasting 


\section{Introduction}

Homicides are declining in all the developed countries. Italy is no exception. The rate of intentional homicides (about 0.74 per 100,000 inhabitants) has dropped by almost $40 \%$ in the past decade and the country currently ranks $68^{\text {th }}$ out of 84 countries worldwide for the rate of this crime (UNODC, 2013). Despite this overall decrease, mafia homicides still represent an alarming issue in specific Italian areas. This is due to the extensive presence of numerous mafia organizations originating from Southern regions but currently present in several others (Calderoni, 2014; Transcrime, 2013). The Campania region and its capital city, Naples, are a dramatic example.

Naples is the third largest Italian city, an important industrial and tertiary hub. It is also a popular tourist destination thanks to its seaside location and its monumental and artistic heritage due to its having served for centuries as the capital of the kingdoms of Naples and of the Two Sicilies (between the twelfth and nineteenth centuries). Despite its advantageous situation, however, Naples reports surprisingly high homicide rates compared to those of Italy and Europe. The Neapolitan average value of intentional homicides in the past ten years (around 3 per 100,000 inhabitants) is about three times higher than the national average in the same period and about double the average of the EU countries' national rates from 2008 to $2014 .^{1}$

A number of media reports and books - for example the semi-documentary bestseller Gomorrah by Roberto Saviano followed by a film and a television series - have recently depicted the persisting violence of the Italian mafia groups (Saviano, 2006). Most of these accounts focus on the last decade, when mafia homicides accounted for an astonishing 60-70\% of all intentional homicides, compared to the national average of about $10-15 \% .^{2}$ The disproportionate concentration of mafia homicides is mainly connected with the historical and organizational evolution of the Camorra, the collective name given to the mafia groups in Campania. Camorra clans are usually smaller than other Italian mafia groups and characterized by lower internal organization and stronger conflicts (Catino, 2014). These characteristics make most of the Camorra groups similar to certain North and South American gangs or maras.

The Neapolitan situation poses a specific question about the solutions that may be implemented to tackle mafia homicides effectively. Specifically, this paper explores the application of a proactive policing approach. Despite the claims that the occurrence of a specific homicide are difficult to predict because of the 
rarity of such crimes and the wide range of their possible motivations (e.g., Szmukler, 2000), this paper hypothesizes that mafia homicides are often linked to a specific place due to the presence, activities, and conflicts of mafia groups. As a consequence, their location can be predicted. This study suggests using the Risk Terrain Modeling method to help law enforcement agencies identify the areas where the risk of a future homicide is higher. The basic idea is that some territorial risk factors can explain the concentrations of crime. Knowing and mapping these risk factors makes it possible to plot a map highlighting the riskiest areas of the city.

The results confirm the hypothesis that mafia homicides can be predicted. The most important predictors are past homicides, drug dealing, and rivalries among groups. The RTM model predicts that up to $85 \%$ of 2012 mafia homicides in Naples occur in the $11 \%$ of the city's areas with highest predicted risk. Furthermore, the model makes it possible to identify the contribution of each predictor to the risk of a specific area, enabling the identification of area-specific preventive policies.

The rest of the paper is organized as follows. The first section reviews the current knowledge about correlates of mafia homicides and suggests some similarities with gang-related violence. The aim of this section is to identify the characteristics that may predict homicides. The second section describes the methodology used, including all the risk factors considered and the procedure followed to define the risk map. The third section presents the data and sources used. The fourth section sets out the results. The last section discusses the implications of the research in regard to defining effective countermeasures and preventive policies.

\section{Organized crime- and gang-related violence}

The combination of environmental and social factors in time and place shapes the criminogenic risk of an area (Caplan, Kennedy, \& Miller, 2011). Research on the social ecology of crime shows that a few places, or "hot spots," systematically concentrate a disproportionally high number of offences (e.g., Eck, Chainey, Cameron, Leitner, \& Wilson, 2005; Weisburd, Groff, \& Yang, 2012). These concentrations are consequential on the characteristics of the environment and of the people that frequent those places (Caplan \& Kennedy, 2016; Eck \& Weisburd, 1995). The law of crime concentration also applies to outdoor serious violence (i.e., homicides, attempted murders, aggravated assaults, gun violence), although the low number of 
events may conceal this pattern (Weisburd, 2015). The research suggests that violent serious crimes concentrate in space and time due to several factors as happens for property crimes (e.g., Braga, Papachristos, \& Hureau, 2009; Ratcliffe \& Rengert, 2008; Summers, 2014; Wells, Wu, \& Ye, 2012).

The risk factors associated with outdoor serious violence include individual, situational, and community factors (Papachristos, Braga, \& Hureau, 2012). Individual factors comprise characteristics of the offenders and the victims (e.g., their age, gender, and race). For example, homicides concentrate among young males and specific sub-populations (Blumstein \& Rosenfeld, 1998; Fagan, Zimring, \& Kim, 1998; D. M. Kennedy \& Braga, 1998). Situational risk factors refer to the presence of drugs, weapons, and other crime facilitators. For instance, shootings are frequent in places where other illicit activities, such as drug dealing, take place (Blumstein, 1995; Lum, 2008); open drug markets often entail violence as a consequence of the simultaneous presence of firearms, young dealers, suitable targets (both profitable street joints and large cash amounts), and intensive law enforcement (Chaiken \& Chaiken, 1990; Reuter, 2009; Tonry, 1990). Furthermore, spatial proximity to episodes of violence and prior homicides help explain the concentration of interpersonal violence in specific locations (Ingram \& Costa, 2016; Morenoff, Sampson, \& Raudenbush, 2001). Community risk factors include the socio-demographic characteristics of the places where crime occurs. Neighborhoods with poor socio-economic conditions, racial inequality, and numerous single-parent families report higher concentrations of interpersonal violence (Curry \& Spergel, 1988; Kirk \& Laub, 2010; Messner \& Zimmerman, 2012; Morenoff et al., 2001; Nieuwbeerta, McCall, Elffers, \& Wittebrood, 2008; Rosenfeld, Bray, \& Egley, 1999; Vilalta \& Muggah, 2014). The population structure and immigration may also influence the variation in homicide rates, with higher proportions of immigrants associated with higher rates of intentional homicides (Land, McCall, \& Cohen, 1990; McCall, Land, \& Parker, 2010; Thompson \& Gartner, 2014).

Violence, and particularly homicides and gun violence, is often associated with the presence of gangs and organized crime groups. Gang or organized crime membership increases an individual's probability of being exposed to gun violence, either as a victim or an offender (Chinnici \& Santino, 1989; Papachristos et al., 2012). Gang or organized crime homicides often target members of the same or rival groups, thus generating a self-propelling spiral of feuds and wars (Binder \& Eghigian, 2013; Catino, 2014; Chinnici \& Santino, 
1989; Cohen \& Tita, 1999; Decker, 1996; Hopkins, Tilley, \& Gibson, 2013; Pizarro \& McGloin, 2006). The combination of gang or organized crime membership and involvement in illicit markets is particularly associated with high levels of interpersonal violence (Binder \& Eghigian, 2013). Gang members involved in drug dealing are generally more violent than both non-dealing members and sellers unrelated to gangs (Bellair \& McNulty, 2009; Decker \& Curry, 2002; Decker, Katz, \& Webb, 2008).

At the local level, the presence of gangs and organized crime increases violent crime rates (Chinnici \& Santino, 1989; D. M. Kennedy, Braga, \& Piehl, 1997; Pyrooz, 2012; Vilalta \& Muggah, 2014). Gang homicides concentrate in specific neighborhoods and show patterns of autocorrelation (Cohen \& Tita, 1999; Decker \& Curry, 2002; Kubrin \& Weitzer, 2003; Mares, 2010; Papachristos \& Kirk, 2006; Rosenfeld et al., 1999; Vilalta \& Muggah, 2014). Gang and organized crime homicides concentrate in densely populated areas, with poor socio-economic conditions, residential instability, and migrant or minority residents (Pyrooz, 2012; Rosenfeld et al., 1999; Vilalta \& Muggah, 2014). The existence of contested drug markets in a city may also lead to the spread of violence among competing groups of criminals, and the presence of gang members helps predict shootings (Cohen \& Tita, 1999; Fagan \& Wilkinson, 1998; Klein, 1995; Ratcliffe \& Taniguchi, 2008). Overall, the presence and activities of gangs and organized crime groups are key factors in determining the levels of homicides in a place.

A growing body of literature focuses on the link between homicidal violence and the social relations of both individuals and criminal groups. Papachristos and colleagues (Papachristos et al., 2012; Papachristos, Wildeman, \& Roberto, 2015; Papachristos \& Wildeman, 2014) contend that, even within high-risk populations, the risk of victimization is not randomly distributed; rather, it is influenced by the characteristics of individuals and their social networks. Personal social networks and their characteristics contribute to identifying subjects at higher risk of becoming perpetrators or victims of violent crime. In particular, the social distance from gunshot victims influences one's probability of victimization (Papachristos et al., 2012).

Social networks have also been used to analyze group processes and their influence on criminal groups' cooffending patterns (Malm, Bichler, \& Nash, 2011) and gang-motivated violence (Papachristos, Hureau, \& Braga, 2013; Tita \& Radil, 2011). Group mechanisms that facilitate violence include inter-group violence, 
group status seeking and management, and reciprocity (Hopkins et al., 2013; Miethe \& Drass, 1999; Papachristos et al., 2013). Gangs usually identify themselves with a place; the protection of the gang's turf or "set space" is one of the factors that may lead to inter-gang violence (Klein, 1995; Tita, Cohen, \& Engberg, 2005). Similarly, organized crime groups often compete to control political and economic resources in a specific area (Chinnici \& Santino, 1989; Moro, Petrella, \& Sberna, 2016). Geographic proximity plays an important role in inter-group conflicts, since violence between gangs tends to concentrate along the boundaries of gangs' turfs (Brantingham, Tita, Short, \& Reid, 2012). Groups may also use violence to demonstrate their prestige to other groups (Hopkins et al., 2013; Kobrin, Puntil, \& Peluso, 1967), and to ensure internal loyalty (Cohen \& Tita, 1999; Decker \& Curry, 2002).

Recently, scholars have demonstrated the relevance of social distance and rivalries, describing the important role that past inter-group conflicts have in the spatial and temporal distribution of homicides and gangrelated violence in US and Canadian cities (Descormiers \& Morselli, 2011; D. M. Kennedy et al., 1997; Papachristos, 2009; Papachristos et al., 2013; Tita \& Greenbaum, 2009; Tita \& Radil, 2011). Indeed, conflicts are often retaliatory in nature (Decker, 1996), and groups use violence as a form of justice to reciprocate a transgression or to respond to a threat by another group (Chinnici \& Santino, 1989; Hopkins et al., 2013; Papachristos, 2009; Papachristos et al., 2013). These studies usually integrate a spatial and a network approach, and show that rivalries between gangs and other groups account for patterns of gang violence more than geographic proximity and neighborhood structural characteristics (Brantingham et al., 2012; Cohen \& Tita, 1999; Papachristos et al., 2013; Tita \& Radil, 2011).

Geography and social networks thus seem to influence the spatial distribution of organized crime- and gangrelated homicides in an urban environment. Prior homicides and neighborhood structural characteristics (e.g.,. socio-economic disadvantage, population structure) help explain the concentration of violence in specific locations. The presence of gangs, organized crime groups, and drug corners are also associated with high levels of violence. Finally, group processes such as rivalries account for inter-group conflicts.

This paper tests the effect of these risk factors on the geographical distribution of mafia-related homicides in Naples, Italy. The risk factors associated with mafia homicides are then used to predict the geographic distribution of mafia-related homicides in the city. 


\section{Methodology}

This study suggests that environmental factors connected with the presence, activities, and conflicts of mafia groups increase the likelihood of a future mafia-related homicide. It aims in particular to demonstrate the predictability of mafia-related homicides. The proposed methodology follows the Risk Terrain Modeling (RTM) approach. First developed by Caplan et al. (2011), this technique provides a spatial risk assessment of specific criminal events focusing on the presence of multiple connected risk factors. Through the identification and validation of these risk factors, it determines a risk map highlighting the areas where the likelihood of future crime is higher. Several studies have tested the reliability of the RTM approach by focusing on different geographical contexts and types of crime or events (Caplan \& Kennedy, 2011; Drawve, Moak, \& Berthelot, 2014; Drawve, Thomas, \& Walker, 2016; Dugato, 2013; Dugato, Caneppele, Favarin, \& Rotondi, 2015; L. W. Kennedy \& Gaziarifoglu, 2011; Kocher \& Leitner, 2015; Moreto \& Caplan, 2010). Two main considerations drive the selection of this approach. First, it does not simply predict the more likely future location of crimes. The diagnostic focus on the risk factors makes it possible to identify the correlates of the criminal events, thus helping law enforcement agencies and local administration to design targeted countermeasures (Caplan \& Kennedy, 2016). Second, several studies have demonstrated the efficiency of the RTM approach in providing reliable and consistent results in comparison with other alternative methodologies (Drawve, 2014; Dugato, 2013).

The RTM approach was implemented through an exercise with historical data on mafia-related homicides that occurred in Naples during 2012. The RTM procedure comprised several steps to identify the risk map used to forecast mafia homicides. Initially, a set of potential risk factors were identified by considering the existing knowledge about the crime under study and the data available. Then, during a primary calibration phase of the model, this initial list of factors was skimmed and validated, defining their associations with mafia homicides ${ }^{3}$ in the previous year (2011). The selected risk factors and the estimates of their associations with mafia homicides were then updated and merged to calculate a final risk score. This final score was finally compared with the actual mafia homicides that occurred in 2012.

The following subsections explain in detail the methodology used, and they describe the risk factors considered. 


\section{Defining the risk map}

The first step was to divide the city of Naples using a regular grid (cell size $1 \mathrm{x} 1 \mathrm{~km}$ ). Although the selected cell size was larger than usual for urban crimes, the choice should be related to the specific type of crime, to the characteristics of the study area, and to the final purpose of the research. Three assumptions drove the choice of $1 \mathrm{x} 1 \mathrm{~km}$ cells. First, mafia homicides are sporadic events whose location is affected by a stochastic variability. Therefore, a larger cell size can capture this uncertainty, ensuring a greater reliability and consistency of the predictions. Second, most mafia homicides occur in public places, and some reports provide only rough information on the location of the crime (i.e., they include only the street name or the address of the closest building). Larger cells compensate for these limitations. Third, given the nature of this crime, future preventive interventions or policies should focus on areas of the city (i.e., neighborhoods) rather than on micro-places (i.e., blocks, street corners). Hence, a cell with a $1 \mathrm{~km}$ side can better mirror the expected focus of these interventions, thus being more useful for law enforcement agencies or policy makers. ${ }^{4}$

The second step was the selection of a set of potential risk factors from the literature (see below for further details). Because of their nature and the available data, risk factors were operationalized as either points or polygons. This implied alternative procedures to assign a value for each risk factor to the cells of the regular grid. For polygons data, the analyses considered the sum of the values of the polygons whose centroids fell within the cell in the case of absolute values and the mean value for the same polygons in the case of rates. Alternative methods of aggregation have been tested (e.g., based on percentage of overlaps). However, the centroid approach provides the most consistent results in comparison with the original distribution of the data. For points data, the analysis considered the count of the events occurring within each cell.

The third step was testing the supposed relations between the risk factors and the outcome variable to select the relevant risk factors. This operation was crucial for assessing the reliability of the theoretical assumptions that guided the preliminary identification of the risk factors. Therefore, the supposed relations were tested statistically by comparing the presence of risk factors with previous mafia homicides. In particular, a Poisson regression model with robust standard error assessed the statistical connections of the risk factors with the 
occurrence of mafia homicides in 2011. The Poisson regression can fit the distribution of a count dependent variable (Coxe, West, \& Aiken, 2009; Hilbe, 2011; Long, 1997).

A Poisson regression model with robust standard error was selected among alternatives (i.e., Negative binomial or zero-inflated Poisson) after testing for the absence of overdispersion and excluding the presence of factors generating an anomalous number of zero values in the dependent variable (i.e., excess of zero). Furthermore a specific test was conducted to assess the possible autocorrelation of the dependent variable and of the residuals. The aim of these controls was to check whether the spatial nature of the data had affected the final results of the model. The results obtained made it possible to exclude any severe autocorrelation.

The final risk value for each cell of the regular grid was a weighted sum of the corresponding values of the significant risk factors. The weights were the coefficients from the regression model. The risk value was determined using the following formula:

$$
\text { Risk value }=\operatorname{Exp}\left(\beta_{0}+\sum_{i=1}^{n} X_{i} \beta_{i}\right) / \operatorname{Exp}\left(\beta_{0}\right)
$$

The predictive power of the risk map was tested by means of another Poisson regression, with the risk value as independent variable and the number of mafia homicides recorded in 2012 as dependent variable. In conclusion, an analysis was conducted of the risk factors structure and homogeneity within the cells at higher risk. $^{5}$

\section{The risk factors}

The objects of the forecast are mafia homicides committed within the city of Naples, Italy. The study specifically considers both attempted and completed homicides. The motivation behind this choice is that usually an attempted mafia or gang-related homicide diverge from an actual one only in its outcome which is often conditioned by accidental factors. Whereas, the two events are rarely different in the motivation of the offenders or in the contextual circumstances (Berk, Sherman, Barnes, Kurtz, \& Ahlman, 2009). Among the many possible factors leading to a mafia homicide, this study focused on six risk factors. 
The first risk factor relates to retaliation. A mafia-related homicide can occur in response to a previous act of violence (Kubrin \& Weitzer, 2003; Papachristos, 2009). Areas close to the location of past mafia homicides may be at risk of future conflicts among mafia groups and murderers.

The second risk factor considered was the number of other intentional non-mafia related homicides occurring in the previous years. This factor was selected for two main reasons. First, it provides an assessment of the general level of violence in the area (Mares, 2010). Second, homicides are classified as mafia-related by the law enforcement agencies usually on the basis of the victim's identity. However, this attribution may be updated or changed after further investigations or the ensuing judicial procedures. Thus, including also homicides not immediately classified as mafia-related may help to adjust this possible bias. For both these risk factors, data on events occurring between 2004 and 2011 were considered.

The third risk factor referred to the illegal activities conducted by mafia members that may generate disputes or rivalries that provoke violent conflicts. In particular, this study focuses on street-level drug dealing as the illegal activity most related to homicides. Drug dealing can cause conflicts for control of open-air drug markets or ones due to failed transactions (Cohen \& Tita, 1999; Howell, 1999). Data on reported cases of drug dealing for 2010 and 2011 were considered.

The fourth risk factor related to the residences of mafia members. Some victims of mafia homicides are killed in ambushes near their or their relatives' homes. Since data on the actual residences of mafia members were not available, this research used the location of residential dwellings confiscated from mafia members in the city of Naples between 2004 and 2011 as a proxy. This and the previous three risk factors were operationalized by counting the number of events (i.e., homicides, reports for drug dealing, and confiscated real estate) that occurred or were located in each cell considered.

The last two risk factors concerned the presence of conflicts among different mafia groups. Available police data made it possible to define the neighborhood presenting internal rivalries (i.e., known conflicts among two or more groups operating or located in the same neighborhood) or external rivalries (i.e., presence of one or more groups in conflict with groups located in other neighborhoods). Several studies have used social network analysis to investigate violence among gangs (R. Block, 2000; D. M. Kennedy, Braga, \& Piehl, 1996; Tita \& Radil, 2011). Most of them have shown that existing conflicts among groups increase the rates 
of violence. Therefore, the neighborhoods experiencing a number of internal and external rivalries above the corresponding means are considered to be at high risk of being the location of future homicides.

\section{Control variables}

The final model included some control variables to prevent spurious effects. First, it considered the population density estimated using the resident population in the census blocks falling within each cell. Denser areas may concentrate more homicides as a direct consequence. Second, it proxied the wealth of areas through the average real estate values for each cell. This allowed to take into account that Mafia groups may tend to avoid violence in the wealthiest neighborhoods. Third, the concentration of mafia groups was operationalized by considering the groups operating in each neighborhood of the city of Naples. A high number of homicides could be the mere consequence of a strong mafia presence. Finally, the model considered the percentages of resident foreigners and of non-working males aged more than 15 years old. The two variables are usually connected with social disadvantages, conflicts, and violent behaviors that may result in homicides (Rosenfeld et al., 1999).

The following table summarizes all the risk factors considered. The table distinguishes between the different timeframes considered for the calibration phase (i.e, for selecting the relevant risk factors) and the final model (i.e., for predicting the mafia-related homicides in 2012).

\section{TABLE 1 ABOUT HERE}

\section{Data}

\section{Data sources}

The data were taken from various sources. Intentional homicides (2004-2012) and drug dealing (2010-2011) derived from the crimes reported by the Italian police forces to the judicial authorities and stored in the joint database (Banca Dati Interforze) of the Italian Ministry of the Interior ( $\mathrm{N}=495$ and $\mathrm{N}=1085$ respectively). Homicides included attempted and completed homicides, and were divided between mafia-related homicides $(\mathrm{N}=181)$ and others $(\mathrm{N}=314)$. Data on confiscated properties (2004-2011) were collected through ANBSC, the Italian Agency for the Management of Seized and Confiscated Assets (N=31). Information about mafia groups active in the city of Naples and their rivalries came from the reports of the Italian Antimafia 
Investigative Direction (DIA), a specialized law enforcement unit. ${ }^{6}$ Data on resident population, foreigners and non-working males derived from the Italian 2011 General Population and Housing Census. The average real estate values related to the second half of 2011 and belonged to the Italian Real Estate and Land Registry Agency (Agenzia del Territorio). The authors collected these datasets and documents during a project on the investments of the Italian mafias for the Ministry of the Interior (Transcrime, 2013). ${ }^{7}$

\section{Geocoding procedure}

Data on homicides and drug dealing were geocoded as punctual data using the information available from law enforcement agencies. About $41 \%$ of the homicides and $53 \%$ of the drug dealing reports considered provided complete and detailed information on the location of the crime (i.e., street name and street number). These percentages were in line with the level of data quality and accuracy experienced in previous studies in Italy using geocoded data (Dugato, 2013; Dugato, Caneppele, et al., 2015; Favarin, 2014; Transcrime, 2011). To improve geocoding precision, homicides reporting a generic address (e.g., only street name but no street number) were validated with information from open sources (e.g., media, news reports, studies). The remaining events reporting at least the name of the street were geocoded by considering the centroids of the streets. The purpose of this choice was to try to maximize the number of events geocoded. Although this choice may have partially biased the data, a detailed analysis on homicide data revealed that most (from 69\% for mafia-related homicides to $60 \%$ for other intentional homicides) of the events not reporting the street number were located in streets shorter than 500 meters. Given the size of the cells $(1 \times 1 \mathrm{Km})$, most of these streets are likely to fall entirely within a single cell. Rather than discarding these events from the analysis, it was preferred to deal with a possible bias (i.e., due to the inaccurate location of these events) rather than having a certain one (i.e., due to the systematic exclusion of events belonging to longer streets). To further test the impact of this potential bias the authors ran the analysis also excluding the addresses reporting incomplete addresses located in streets longer than 500m. The results remained stable and almost identical.

The results are therefore based on analyses that omitted only the events with totally missing or non-existent addresses, corresponding to less than $1 \%$ of the total sample for mafia homicides and $2 \%$ for other homicides. 
Data on confiscated assets were geocoded as punctual data using the address of the property. Information about the active mafia groups and their rivalries were located at neighborhood level $(\mathrm{N}=31)$. Census data were located at census block $(\mathrm{N}=4301)$, whereas real estate values were aggregated into 68 areas defined by the Italian Real Estate and Land Registry Agency.

\section{Results}

The first analysis regarded the actual connections between the selected risk factors and the mafia homicides occurring in 2011. It selected the risk factors relevant to defining the final map forecasting the risk of mafia homicides in 2012. The Poisson regression model showed that five out of six risk factors were positively and significantly connected with the presence of mafia homicides controlling for the other regressors in the model (Table 1). Prior homicides in the same cell increased the likelihood of future mafia homicides. In particular, for each mafia-related homicide occurring in the previous years, the probability that a mafia homicide would happen in the next year increased by $25 \%$. For each non-mafia-related homicide, the same probability increased by $16 \%$. Also the presence of drug markets is important, yielding a $2 \%$ increase in the probability of a future mafia homicide for each reported case of drug dealing in the previous 12 months.

Interestingly, the presence of a residential dwelling confiscated from mafia members increases significantly the likelihood of a mafia homicide. As supposed, these properties could identify the areas where the mafia members are more likely to live and operate steadily. This finding also confirms, at micro level, the results of a previous study demonstrating that Italian mafia groups tend to invest in real estate in areas where their presence and control is higher (Dugato, Favarin, \& Giommoni, 2015).

Rivalries among mafia groups have a remarkable impact. Only cells in neighborhoods with internal rivalries above the city average had a significantly higher probability of future mafia homicides. Contrarily, cells with high external rivalries lacked any statistically significant impact on the probability of mafia homicides in the next year, when controlling for the other factors. This last risk factor was accordingly omitted from calculation of the risk map. Among the control variables, only the number of mafia groups active in the area was significantly connected with mafia homicides. Thus, it was included in the calculation of the final risk values. 


\section{TABLE 2 ABOUT HERE}

Figure 1 shows the final risk map derived for 2012. As said, for each of the 162 cells the risk value was calculated as a weighted sum of the values of the significant predictors resulting from the Poisson regression model. The map identifies 9 out of 162 cells at a very high risk corresponding to a relative risk value higher than 10 (i.e. the probability of a mafia homicide is 10 times higher than in a cell with no risk factors), and 8 other cells at high risk having relative risk values between 3 and 10. The map classifies about $11 \%$ of the area of the city as at risk of future mafia homicides. Specifically, it identifies two clusters of risky cells: one in the city center and one in the north of the city (Scampia-Miano - Secondigliano).

\section{FIGURE 1 ABOUT HERE}

Comparison of this forecast with the actual mafia homicides occurring in 2012 enables assessment of the predictive power and the reliability of this method. $85 \%$ of the mafia homicides (17 out of 20) committed in 2012 are located within cells at high or very high risk (Table 2). This result shows that mafia homicides in Naples follow a concentration pattern very similar to the so-called "Pareto Principle", suggesting that crime, like many other events, concentrates disproportionately in very few locations (Weisburd et al., 2012).

\section{TABLE 3 ABOUT HERE}

A second Poisson regression model enabled better specification of the changes in the likelihood of future homicides from one risk level to another. The model had the number of mafia homicides recorded in 2012 as the dependent variable and three dummies expressing the risk levels of the cells. Low risk was the reference category omitted. The results (Table 3) show that the few cells with a very high or high risk have a significantly higher probability of being the location of a mafia homicide in comparison with the ones categorized as being at very low risk. This probability is almost 48 times higher for cells at very high risk and almost 38 times higher for areas at high risk if compared to the reference category.

\section{TABLE 4 ABOUT HERE}

The RTM approach does not only provide a risk assessment of the likelihood of a future crime. One of its most important benefits is that it highlights the relevant risk factors determining this risk (Perry, 2013). This 
is crucial for defining targeted policies and interventions. The following maps (Figure 2) show the internal structure of the risk factors in each cell categorized as risky. In particular, the backgrounds of the cells identify the risk factors with the greatest impact in determining the risk value. On the first map, the histograms provide an overview on how the various risk factors combine in each cell. It emerges that the influence of a particular risk factor is clearly prevalent in some areas, whereas in others the risk structure is more balanced. The second map further clarifies this difference by reporting the value of a homogeneity index for each cell. The index was calculated starting from the relative influence of each factor in composing the risk value (Corbetta, Gasperoni, \& Pisati, 2001). The closer this value is to one, the more homogenous and unbalanced is the risk factor structure of the cell. The map shows that the homogeneity is higher in the cells composing the northern risk cluster, which means that one risk factor is clearly predominant in the composition of the final value. By contrast, the risk cluster close to the city center is more balanced in its composition, denoting a more complex environmental setting.

\section{FIGURE 2 ABOUT HERE}

\section{Discussion and conclusions}

This study has identified the correlates of mafia homicides in Naples at the micro-level and successfully applied the RTM approach to predict 2012 mafia homicides.

The correlates of mafia homicides in Naples are remarkably consistent with the findings of the international literature on organized and gang-related violence. Camorra activities and inter-group relations are the most important drivers of mafia homicides. Mafia homicides in previous years increase the risk of further mafia homicides, confirming that the spatial concentration of homicides is constant over an extended period (Braga et al., 2009; Ratcliffe \& Rengert, 2008; Wells et al., 2012).

Rivalries within the same neighborhood significantly increase the probability of Camorra homicides. Clans often compete for neighborhoods and drug-selling areas, and aggressive competition is often the cause of homicides, with dynamics that closely resemble the turf-related gang violence observed in several US cities (C. R. Block \& Block, 1993; Tita et al., 2005; Valdez, Cepeda, \& Kaplan, 2009). The role of internal rivalries is consistent with studies showing that gang violence clusters at the border between gang territories 
(C. R. Block \& Block, 1993, p. 8; Brantingham et al., 2012, p. 873). Brantingham and colleagues also showed that the formation and competition for gang territory explains a large proportion of violent events (Brantingham et al., 2012). Analysis of the structure and homogeneity of the risk factors in Naples shows that rivalries within the same neighborhood have a prominent role particularly in the northern risk cluster (Figure 1). The cluster comprises two infamous neighborhoods, Scampia and Secondigliano, which experienced several Camorra feuds in the last decade, as also portrayed in the popular book Gomorrah (Saviano, 2006) and the film and television series that it inspired (Garrone, 2008; Sollima, 2014).

Other intentional homicides are also directly associated with Camorra homicides. Violence - either with or without a clear link to organized crime - seems to affect particular areas of the city disproportionately. The positive association between mafia-related and other homicides may partly be the consequence of crime classification rules that underestimate the former and overestimate the latter. For example, intentional homicides normally include also accidental victims of Camorra gunfights - not infrequent occurrences also reported by the international media (BBC News, 2004; McKenna, 2014) - or events not yet classified as mafia-related. Moreover, research has shown that homicides of different types may follow similar spatial distributions (Rosenfeld et al., 1999).

Variables controlling for the socio-economic conditions of areas are not significant in the RTM model on Naples. This suggests that more traditional explanations of gang violence, like social disorganization or deprivation, have no particular pertinence to Camorra homicide, once mafia-related variables are included in the model. These results may appear to contradict the assumption in the literature that social disorganization and poverty favor the emergence of gangs and, in turn, gang homicides (e.g.,. Cartwright \& Howard, 1966; Curry \& Spergel, 1988). However, previous research has found that inter-group conflicts account for patterns of gang violence more than neighborhood characteristics (Brantingham et al., 2012; Papachristos et al., 2013; Tita \& Radil, 2011), and our study corroborates these results in a different context.

The RTM approach successfully predicted that $85 \%$ of mafia homicides occurring in 2012 would take place in an area as small as $11 \%$ of the city of Naples. But simply forecasting the location of future Camorra homicides is not enough to define effective countermeasures. The results of this study also show that, even in a restricted space, the same risk factors may combine in different ways, giving rise to areas of equal risk but 
requiring targeted remedies. The RTM approach enables identification of these combinations of potential criminogenic features in the urban fabric, thus paving the way for the design of proactive and effective measures. For example, in the neighborhoods where internal conflicts are the most relevant factors, an active monitoring of the organizational dynamics of the Camorra and particularly of rivalries among groups and factions may improve the reliability of predictions and provide investigators with intelligence useful for disrupting the criminal organizations (e.g., arresting new formations at an early stage or recruiting informants). Instead, in areas mostly characterized by drug-related activities, an increased law enforcement presence may deter gunfights in open public spaces and decrease the profitability of drug-selling (Mohler, 2014). These policies could effectively complement traditional welfare policies addressing neighborhoods with poor socio-economic conditions (e.g., programs tackling school abandonment, long-term unemployment, and social distress in general) or awareness campaigns to reduce the social support enjoyed by Camorra groups.

This study may be helpful for the Italian authorities, but some of the findings may also be valid and useful beyond national borders. Considering the similarities between the Camorra groups and other gangs or organized crime groups, a similar approach incorporating an analysis of geographical information at micro level, as well as data on rivalry networks, may also provide significant added value for practitioners and local administrators operating in other countries.

To the best of our knowledge, this is the first study predicting mafia homicides. While the results show that successful predictions are possible, the research had a number of limitations which should be addressed in the future. The availability and quality of data was the most important constraint. Access to street-level homicide data in Naples was provided in the context of a wider research project for the Italian Ministry of Interior. The data are not publicly available and periodically updated. As discussed above, some events lacked the street and/or the street number. The analysis imputed some missing information, and this procedure may have biased the results, although to an acceptable extent. Considering the seriousness and limited number of homicides in Italy, administrative data collection efforts should improve the data quality and ensure that the exact location is fully reported. Furthermore, the current data do not systematically report the name of the victim and other important circumstances. Consequently, it was impossible to link mafia 
homicides clearly with specific conflicts between factions or groups, or to distinguish among the motivations for the homicides. Data on internal and external rivalries and group positions derived from intelligence reports served to provide a general overview on the Camorra situation in Naples. While officers on the ground are probably aware of the most recent evolutions in the Neapolitan Camorra, these reports furnished a mere summary of much more dynamic processes. Improving the accuracy of these sources may require a more systematic reporting of group territories and rivalries. Although this may require a relatively small organizational change, it may yield a large operational benefit. 


\section{References}

BBC News. (2004). BBC NEWS | Europe | Girl hit in Mafia shooting dies. Retrieved October 18, 2016, from http://news.bbc.co.uk/2/hi/europe/3577569.stm

Bellair, P. E., \& McNulty, T. L. (2009). Gang Membership, Drug Selling, and Violence in Neighborhood Context. Justice Quarterly, 26(4), 644-669. https://doi.org/10.1080/07418820802593394

Binder, J. J., \& Eghigian, M. (2013). Gangland Killings in Chicago, 1919-1933. Journal of Contemporary Criminal Justice, 29(2), 219-232. https://doi.org/10.1177/1043986213485632

Block, C. R., \& Block, R. (1993). Street gang crime in Chicago. Washington, D.C.: U.S. Dept. of Justice, Office of Justice Programs, National Institute of Justice. Retrieved from //catalog.hathitrust.org/Record/003514601

Block, R. (2000). Gang activity and overall levels of crime: A new mapping tool for defining areas of gang activity using police records. Journal of Quantitative Criminology, 16(3), 369-383.

Blumstein, A. (1995). Youth violence, guns, and the illicit-drug industry. Journal of Criminal Law and Criminology, 86, 10-36.

Blumstein, A., \& Rosenfeld, R. (1998). Explaining recent trends in U.S. homicide rates. Journal of Criminal Law and Criminology, $88(4), 1175-1216$.

Braga, A. A., Papachristos, A. V., \& Hureau, D. M. (2009). The Concentration and Stability of Gun Violence at Micro Places in Boston, 1980-2008. Journal of Quantitative Criminology, 26(1), 33-53. https://doi.org/10.1007/s10940-009-9082-x

Brantingham, P. J., Tita, G. E., Short, M. B., \& Reid, S. E. (2012). The Ecology of Gang Territorial Boundaries. Criminology, 50(3), 851-885.

Calderoni, F. (2014). Measuring the Presence of the Mafias in Italy. In S. Caneppele \& F. Calderoni (Eds.), Organized Crime, Corruption and Crime Prevention (pp. 239-249). New York: Springer International Publishing. Retrieved from http://link.springer.com/chapter/10.1007/978-3-319-01839-3_27

Caplan, J. M., \& Kennedy, L. W. (Eds.). (2011). Risk terrain modeling compendium. Newark, NJ: Rutgers Center on Public Security. Retrieved from http://www.rutgerscps.org/rtm/RiskTerrainModelingCompendium_CaplanKennedy2011.pdf

Caplan, J. M., \& Kennedy, L. W. (2016). Risk terrain modeling: crime prediction and risk reduction. Retrieved from http://search.ebscohost.com/login.aspx?direct=true\&scope=site \&db=nlebk\&db=nlabk\&AN=1218464

Caplan, J. M., Kennedy, L. W., \& Miller, J. (2011). Risk Terrain Modeling: Brokering Criminological Theory and GIS Methods for Crime Forecasting. Justice Quarterly, 28(2), 360-381.

Cartwright, D. S., \& Howard, K. I. (1966). Multivariate Analysis Of Gang Delinquency: I. Ecologic Influences. Multivariate Behavioral Research, 1(3), 321-371. https://doi.org/10.1207/s15327906mbr0103_5

Catino, M. (2014a). How Do Mafias Organize? European Journal of Sociology / Archives Européennes de Sociologie, 55(2), 177220. https://doi.org/10.1017/S0003975614000095

Catino, M. (2014b). How Do Mafias Organize?: Conflict and Violence in Three Mafia Organizations. Archives Européennes de Sociologie, 55(2), 177-220. https://doi.org/http://dx.doi.org/10.1017/S0003975614000095

Chaiken, J. M., \& Chaiken, M. R. (1990). Drugs and Predatory Crime. Crime and Justice, 13, 203-239. 
Chinnici, G., \& Santino, U. (1989). La violenza programmata : omicidi e guerre di mafia a Palermo dagli anni '60 ad oggi. Milano: FrancoAngeli.

Cohen, J., \& Tita, G. (1999). Diffusion in Homicide: Exploring a General Method for Detecting Spatial Diffusion Processes. Journal of Quantitative Criminology, 15(4), 451-493. https://doi.org/10.1023/A:1007596225550

Corbetta, P., Gasperoni, G., \& Pisati, M. (2001). Statistica per la ricerca sociale. Bologna: il Mulino.

Coxe, S., West, S. G., \& Aiken, L. S. (2009). The Analysis of Count Data: A Gentle Introduction to Poisson Regression and Its Alternatives. Journal of Personality Assessment, 91(2), 121-136. https://doi.org/10.1080/00223890802634175

Curry, G. D., \& Spergel, I. A. (1988). Gang Homicide, Delinquency, and Community. Criminology, 26(3), 381-406. https://doi.org/10.1111/j.1745-9125.1988.tb00847.x

Decker, S. H. (1996). Collective and normative features of gang violence. Justice Quarterly, 13, 243-264.

Decker, S. H., \& Curry, G. D. (2002). Gangs, gang homicides, and gang loyalty: Organized crimes or disorganized criminals. Journal of Criminal Justice, 30(4), 343-352. https://doi.org/10.1016/S0047-2352(02)00134-4

Decker, S. H., Katz, C. M., \& Webb, V. J. (2008). Understanding the Black Box of Gang Organization: Implications for Involvement in Violent Crime, Drug Sales, and Violent Victimization. Crime \& Delinquency, 54(1), $153-172$. https://doi.org/10.1177/0011128706296664

Descormiers, K., \& Morselli, C. (2011). Alliances, Conflicts, and Contradictions in Montreal's Street Gang Landscape. International Criminal Justice Review, 21(3), 297-314. https://doi.org/10.1177/1057567711418501

Drawve, G. (2014). A Metric Comparison of Predictive Hot Spot Techniques and RTM. Justice Quarterly, 1-29. https://doi.org/10.1080/07418825.2014.904393

Drawve, G., Moak, S. C., \& Berthelot, E. R. (2014). Predictability of gun crimes: a comparison of hot spot and risk terrain modelling techniques. Policing and Society, O(0), 1-20. https://doi.org/10.1080/10439463.2014.942851

Drawve, G., Thomas, S. A., \& Walker, J. T. (2016). Bringing the physical environment back into neighborhood research: The utility of RTM for developing an aggregate neighborhood risk of crime measure. Journal of Criminal Justice, 44, 21-29. https://doi.org/10.1016/j.jcrimjus.2015.12.002

Dugato, M. (2013). Assessing the Validity of Risk Terrain Modeling in a European City: Preventing Robberies in the City of Milan. Crime Mapping: A Journal of Research and Practice, 5(1), 63-89.

Dugato, M., Caneppele, S., Favarin, S., \& Rotondi, M. (2015). Prevedere i furti in abitazione (Transcrime Research in Brief). Trento: Transcrime - Università degli Studi di Trento.

Dugato, M., Favarin, S., \& Giommoni, L. (2015). The Risks and Rewards of Organized Crime Investments in Real Estate. British Journal of Criminology, 55(5), 944-965. https://doi.org/10.1093/bjc/azv002

Eck, J. E., Chainey, S., Cameron, J. G., Leitner, M., \& Wilson, R. E. (2005). Mapping crime: Understanding hot spots. Washington, DC: National Institute of Justice.

Eck, J. E., \& Weisburd, D. (Eds.). (1995). Crime and Place: Crime Prevention Studies (Vol. 4). Monsey, N.Y.; Washington, D.C.: Willow Tree Pr. 
Fagan, J. A., \& Wilkinson, D. L. (1998). Guns, youth violence, and social identity in inner cities. In M. Tonry \& M. Moore (Eds.), Crime and justice: Annual review of research (Vol. 24, pp. 105-188). Chicago, IL: University of Chicago Press.

Fagan, J. A., Zimring, F. E., \& Kim, J. (1998). Declining homicide in New York City: A tale of two trends. Journal of Criminal Law and Criminology, 88(4), 1277-1323.

Favarin, S. (2014). Testing the law of crime concentrations in Europe. Università Cattolica del Sacro Cuore, Milan, Italy.

Garrone, M. (2008). Gomorra.

Hilbe, J. M. (2011). Negative binomial regression (2nd ed). Cambridge, UK ; New York: Cambridge University Press.

Hopkins, M., Tilley, N., \& Gibson, K. (2013). Homicide and Organized Crime in England. Homicide Studies, 17(3), $291-313$. https://doi.org/10.1177/1088767912461786

Howell, J. C. (1999). Youth Gang Homicides: A Literature Review. Crime \& Delinquency, 45(2), $208-241$. https://doi.org/10.1177/0011128799045002003

Ingram, M. C., \& Costa, M. M. da. (2016). A Spatial Analysis of Homicide Across Brazil's Municipalities. Homicide Studies, 1088767916666603. https://doi.org/10.1177/1088767916666603

Kennedy, D. M., \& Braga, A. A. (1998). Homicide in Minneapolis: Research for problem solving. Homicide Studies, 2, $263-290$.

Kennedy, D. M., Braga, A. A., \& Piehl, A. M. (1997). Mapping gangs and gang violence in Boston. In D. Weisburd \& T. McEwen (Eds.), Crime Mapping \& Crime Prevention. Monsey, NY: Criminal Justice Press.

Kennedy, D. M., Braga, A., \& Piehl, A. M. (1996). The (un) known universe: mapping gangs and gang violence in Boston. Program in Criminal Justice Policy and Management, John F. Kennedy School of Government, Harvard University. Retrieved from http://www.popcenter.org/library/crimeprevention/volume_08/08-Kennedy.pdf

Kennedy, L. W., \& Gaziarifoglu, Y. (2011). Applying RTM to Street Robberies. In J. M. Caplan \& L. W. Kennedy (Eds.), Risk terrain modeling compendium (pp. 73-78). Newark, NJ: Rutgers Center on Public Security.

Kirk, D. S., \& Laub, J. (2010). Neighborhood Change and Crime in the Modern Metropolis. In M. Tonry (Ed.), Crime and Justice: A Review of Research (pp. 41-52). Chicago, IL: University of Chicago Press.

Klein, M. W. (1995). The American street gang. London: Oxford University Press.

Kobrin, S., Puntil, J., \& Peluso, E. (1967). Criteria of Status among Street Groups. Journal of Research in Crime and Delinquency, 4(1), 98-118. https://doi.org/10.1177/002242786700400107

Kocher, M., \& Leitner, M. (2015). Forecasting of Crime Events Applying Risk Terrain Modeling. GI_Forum, 1, 30-40. https://doi.org/10.1553/giscience2015s30

Kubrin, C. E., \& Weitzer, R. (2003). Retaliatory Homicide: Concentrated Disadvantage and Neighborhood Culture. Social Problems, 50(2), 157-180. https://doi.org/10.1525/sp.2003.50.2.157

Land, K. C., McCall, P. L., \& Cohen, L. E. (1990). Structural Covariates of Homicide Rates: Are there any Invariances across Time and Social Space. American Journal of Sociology, 95, 922-963.

Long, S. J. (1997). Regression Models for Categorical and Limited Dependent Variables. Thousand Oaks, CA: SAGE Publications, Inc. 
Lum, C. (2008). The geography of drug activity and violence: Analyzing spatial relationships of non-homogeneous crime event types. Substance Use \& Misuse, 43, 179-201.

Malm, A. E., Bichler, G. M., \& Nash, R. (2011). Co-offending between criminal enterprise groups. Global Crime, 12(2), 112-128.

Mares, D. (2010). Social Disorganization and Gang Homicides in Chicago: A Neighborhood Level Comparison of Disaggregated Homicides. Youth Violence and Juvenile Justice, 8(1), 38-57. https://doi.org/10.1177/1541204009339006

McCall, P. L., Land, K. C., \& Parker, K. F. (2010). An Empirical Assessment of What We Know about Structural Covariates of Homicide Rates: A Return to a Classic 20 Years Later. Homicide Studies, 14, 219-243.

McKenna, J. (2014, July 29). Italy outrage after pensioner mistakenly shot dead in mafia hit. The Telegraph. Rome. Retrieved from http://www.telegraph.co.uk/news/worldnews/europe/italy/10997612/Italy-outrage-after-pensioner-mistakenly-shot-dead-inmafia-hit.html

Messner, S. F., \& Zimmerman, G. M. (2012). Community-Level Influences on Crime and Offending. In B. C. Welsh \& D. P. Farrington (Eds.), The Oxford Handbook of Crime Prevention (pp. 155-171). New York, NY: Oxford University Press.

Miethe, T. D., \& Drass, K. A. (1999). Exploring the Social Context of Instrumental and Expressive Homicides: An Application of Qualitative Comparative Analysis. Journal of Quantitative Criminology, 15(1), 1-21. https://doi.org/10.1023/A:1007550704282

Mohler, G. (2014). Marked point process hotspot maps for homicide and gun crime prediction in Chicago. International Journal of Forecasting, 30(3), 491-497. https://doi.org/10.1016/j.ijforecast.2014.01.004

Morenoff, J. D., Sampson, R. J., \& Raudenbush, S. W. (2001). Neighborhood Inequality, Collective Efficacy, and the Spatial Dynamics of Urban Violence. Criminology, 39(3), 517-558.

Moreto, W. D., \& Caplan, J. M. (2010, April). Forecasting Global Maritime Piracy Utilizing the Risk Terrain Modeling (RTM) Approach. Rutgers Center on Public Security.

Moro, F. N., Petrella, A., \& Sberna, S. (2016). The Politics of Mafia Violence: Explaining Variation in Mafia Killings in Southern Italy (1983-2008). Terrorism and Political Violence, 28(1), 90-113. https://doi.org/10.1080/09546553.2014.880835

Nieuwbeerta, P., McCall, P. L., Elffers, H., \& Wittebrood, K. (2008). Neighborhood Characteristics and Individual Homicide Risks: Effects of Social Cohesion, Confindence in the Police, and Socioeconomic Disadvantage. Homicide Studies, 12, 90-116.

Papachristos, A. V. (2009). Murder by Structure: Dominance Relations and the Social Structure of Gang Homicide. American Journal of Sociology, 115(1), 74-128.

Papachristos, A. V., Braga, A. A., \& Hureau, D. M. (2012). Social Networks and the Risk of Gunshot Injury. Journal of Urban Health: Bulletin of the New York Academy of Medicine, 89(6), 992-1003.

Papachristos, A. V., Hureau, D. M., \& Braga, A. A. (2013). The Corner and the Crew: The Influence of Geography and Social Networks on Gang Violence. American Sociological Review, 78(3), 417-447.

Papachristos, A. V., \& Kirk, D. S. (2006). Neighborhood Effects on Street Gang Behavior. In J. F. Short \& L. A. Hughes (Eds.), Studying Youth Gangs. Lanham, MD: Altamira. 
Papachristos, A. V., \& Wildeman, C. (2014). Network Exposure and Homicide Victimization in an African American Community. American Journal of Public Health, 104(1), 143-150.

Papachristos, A. V., Wildeman, C., \& Roberto, E. (2015). Tragic, but not random: The social contagion of nonfatal gunshot injuries. Social Science \& Medicine, 125, 139-150.

Perry, W. L. (2013). Predictive policing: the role of crime forecasting in law enforcement operations. Santa Monica, CA: RAND.

Pizarro, J. M., \& McGloin, J. M. (2006). Explaining gang homicides in Newark, New Jersey: Collective behavior or social disorganization? Journal of Criminal Justice, 34(2), 195-207. https://doi.org/10.1016/j.jcrimjus.2006.01.002

Pyrooz, D. C. (2012). Structural Covariates of Gang Homicide in Large U.S. Cities. Journal of Research in Crime and Delinquency, 49(4), 489-518.

Ratcliffe, J. H., \& Rengert, G. F. (2008). Near-Repeat Patterns in Philadelphia Shootings. Security Journal, 21, 58-76.

Ratcliffe, J. H., \& Taniguchi, T. A. (2008). Is Crime Higher Aroung Drug-Gang Street Corners? Two Spatial Approaches to the Relationship Between Gang Set Spaces and Local Crime Levels. Crime Patterns and Analysis, 1(1), 23-46.

Reuter, P. (2009). Systemic violence in drug markets. Crime, Law and Social Change, 52(3), $275-284$. https://doi.org/10.1007/s10611-009-9197-x

Rosenfeld, R., Bray, T. M., \& Egley, A. (1999). Facilitating Violence: A Comparison of Gang-Motivated, Gang-Affiliated, and Nongang Youth Homicides. Journal of Quantitative Criminology, 15(4), 495-516.

Saviano, R. (2006). Gomorra: viaggio nell'impero economico e nel sogno di dominio della camorra. Milano: Mondadori.

Sollima, S. (2014, 2016). Gomorra: La serie. Italy.

Summers, L. (2014). Outdoor Serious Violence: The Role of Place. In G. Bruinsma \& D. Weisburd (Eds.), Encyclopedia of Criminology and Criminal Justice (p. 3408). New York: Springer.

Szmukler, G. (2000). Homicide inquiries. The Psychiatrist, 24(1), 6-10.

Thompson, S. K., \& Gartner, R. (2014). The Spatial Distribution and Social Context of Homicide in Toronto's Neighborhoods. Journal of Research in Crime and Delinquency, 51(1), 88-118.

Tita, G. E., Cohen, J., \& Engberg, J. (2005). An Ecological Study of the Location of Gang “Set Space.” Social Problems, 52(2), 272299. https://doi.org/10.1525/sp.2005.52.2.272

Tita, G. E., \& Greenbaum, R. T. (2009). Crime, Neighborhoods, and Units of Analysis: Putting Space in its Place. In D. Weisburd, W. Bernasco, \& G. Bruinsma (Eds.), Putting Crime in its Place: Units of Analysis in Geographic Criminology (pp. 145170). New York, NY: Springer.

Tita, G. E., \& Radil, S. M. (2011). Spatializing the Social Networks of Gangs to Explore Patterns of Violence. Journal of Quantitative Criminology, 27(4), 521-545. https://doi.org/10.1007/s10940-011-9136-8

Tonry, M. (1990). Research on Drugs and Crime. Crime and Justice, 13, 1-8. https://doi.org/10.1086/449171

Transcrime. (2011). La criminalità nelle aree metropolitane: progetto sperimentale per la costruzione e l'analisi degli hot spot della criminalità nel comune di Milano. (M. Dugato, Ed.). Transcrime. 
Transcrime. (2013). Project NOP Security 2007-2013: Mafias Investments. Report Line 1. Rome: : Italian Ministry of Interior. Retrieved from http://www.investimentioc.it/index.htm

UNODC. (2013). 2013 Global Study on Homicide. Vienna: United Nations Office on Drugs and Crime (UNODC).

Valdez, A., Cepeda, A., \& Kaplan, C. (2009). Homicidal Events Among Mexican American Street Gangs A Situational Analysis. Homicide Studies, 13(3), 288-306. https://doi.org/10.1177/1088767909336328

Vilalta, C., \& Muggah, R. (2014). Violent disorder in Ciudad Juarez: a spatial analysis of homicide. Trends in Organized Crime, 17(3), 161-180. https://doi.org/10.1007/s12117-014-9213-0

Weisburd, D. (2015). The Law of Crime Concentration and the Criminology of Place*. Criminology, 53(2), $133-157$. https://doi.org/10.1111/1745-9125.12070

Weisburd, D., Groff, E. R., \& Yang, S.-M. (2012). The Criminology of Place: Street Segments and Our Understanding of the Crime Problem (1 edition). Oxford; New York: Oxford University Press.

Wells, W., Wu, L., \& Ye, X. (2012). Patterns of Near-Repeat Gun Assaults in Houston. Journal of Research in Crime and Delinquency, 49(2), 186-212. https://doi.org/10.1177/0022427810397946 


\section{TABLES}

Table 1- Variables considered and corresponding years, distinguishing the calibration phase to the final model

\begin{tabular}{lccc}
\hline Variables & \multicolumn{2}{c}{ Years } & Source \\
\hline \multicolumn{1}{l}{ Outcome } & Calibration phase & Final Model & \\
$\begin{array}{l}\text { Mafia homicides } \\
\quad \text { Risk factors }\end{array}$ & 2011 & 2012 & Italian Ministry of the Interior \\
Mafia homicides (previous) & $2004-2010$ & $2004-2011$ & Italian Ministry of the Interior \\
Other homicides & $2004-2010$ & $2004-2011$ & Italian Ministry of the Interior \\
Drug dealing & 2010 & 2011 & Italian Ministry of the Interior \\
Confiscated Real Estate & $2004-2010$ & $2004-2011$ & ANBSC \\
Rivalries & 2012 & 2012 & Antimafia Investigative Direction \\
$\quad$ Control variables & 2011 & 2011 & Real Estate and Land Registry Agency \\
Real Estate values & 2012 & 2012 & Antimafia Investigative Direction \\
Number of mafia groups & 2011 & 2011 & Population and Housing Census \\
Population Density & 2011 & 2011 & Population and Housing Census \\
$\%$ Foreigners & 2011 & 2011 & Population and Housing Census \\
\hline Non-working males & & & \\
\hline
\end{tabular}


Table 2- Poisson regression models identifying factors associated with Mafia homicides $(\mathrm{N}=162)$

$\begin{array}{lrlrrr}\text { Wald chi2 (11) } & 144.12 & \text { Log pseudo-likelihood } & -40.173 & \text { BIC } & -682.793 \\ \text { Prob > chi2 } & 0.000 & \text { Pseudo R2 } & 0.405 & & \end{array}$

\begin{tabular}{|c|c|c|c|c|c|}
\hline & Coef. & $\begin{array}{l}\text { Robust } \\
\text { Std.Err. }\end{array}$ & $\mathrm{z}$ & $\mathrm{P}>|\mathrm{z}|$ & IRR \\
\hline \multicolumn{6}{|l|}{ Risk factors } \\
\hline Mafia homicides 2004-10 & $0.2207 * * *$ & 0.0688 & 3.21 & 0.001 & 1.2469 \\
\hline Other homicides $2004-10$ & $0.1442 * *$ & 0.0720 & 2.00 & 0.045 & 1.1551 \\
\hline Drug dealing 2010 & $0.0185 * *$ & 0.0075 & 2.45 & 0.014 & 1.0186 \\
\hline Confiscated Real Estate 2004-10 & $0.3204 *$ & 0.1889 & 1.70 & 0.090 & 1.3777 \\
\hline Internal rivalries (> mean) & $1.7451 *$ & 0.9506 & 1.84 & 0.066 & 5.7266 \\
\hline External rivalries (> mean) & -0.2810 & 0.7131 & -0.39 & 0.694 & \\
\hline \multicolumn{6}{|l|}{ Control variables } \\
\hline Real Estate values 2011 & -0.0002 & 0.0004 & -0.53 & 0.595 & \\
\hline Number of mafia groups & $-0.6714 *$ & 0.3572 & -1.88 & 0.060 & 0.5109 \\
\hline Population Density 2011 & -0.0416 & 0.0429 & -0.97 & 0.332 & \\
\hline \% Foreigners 2011 & -6.2709 & 8.0116 & -0.78 & 0.434 & \\
\hline \% Non-working males 2011 & -0.1998 & 2.8570 & -0.07 & 0.944 & \\
\hline Constant & -1.3148 & 1.3457 & -0.98 & 0.329 & \\
\hline
\end{tabular}

Dependent: Mafia homicides 2011

$* p \leq 0.10^{* *} p \leq 0.05^{* * *} p \leq 0.01$

Table 3 - Number of cells by risk value and mafia homicides occurred

\begin{tabular}{lcccccc}
\hline Risk Value & Cells & $\mathbf{\%}$ & $\begin{array}{c}\text { \% } \\
\text { cumulative }\end{array}$ & $\begin{array}{c}\text { Mafia } \\
\text { homicides } \\
\mathbf{2 0 1 2}\end{array}$ & $\boldsymbol{\%}$ & $\begin{array}{c}\text { \% } \\
\text { cumulative }\end{array}$ \\
\hline Very High $[\geq 10]$ & 9 & $6 \%$ & $6 \%$ & 8 & $40 \%$ & $40 \%$ \\
High $(3 ; 10]$ & 8 & $5 \%$ & $11 \%$ & 9 & $45 \%$ & $85 \%$ \\
Medium $(1 ; 3]$ & 17 & $10 \%$ & $21 \%$ & 0 & $0 \%$ & $85 \%$ \\
Low $[\leq 1]$ & 128 & $79 \%$ & $100 \%$ & 3 & $15 \%$ & $100 \%$ \\
\hline Total & 162 & $100 \%$ & & 20 & $100 \%$ &
\end{tabular}


Table 4 - Poisson regression models assessing the predictive power of the final risk map ( $N=162)$

\begin{tabular}{|c|c|c|c|c|}
\hline Wald chi2 (11) & 2642.12 & Log pseudo-likelihood & -37.786 & BIC \\
\hline Prob > chi 2 & 0.000 & Pseudo R2 & 0.448 & \\
\hline
\end{tabular}

\begin{tabular}{|c|c|c|c|c|c|}
\hline & Coef. & $\begin{array}{l}\text { Robust } \\
\text { Std.Err. }\end{array}$ & $\mathrm{z}$ & $\mathrm{P}>|\mathrm{z}|$ & IRR \\
\hline Very High risk & $3.8712 * * *$ & 0.716 & 5.410 & 0.000 & 47.9997 \\
\hline High risk & $3.6356 * * *$ & 0.660 & 5.510 & 0.000 & 37.9248 \\
\hline Medium risk & $-14.2860 * * *$ & 0.622 & -22.970 & 0.000 & $6.25 \mathrm{E}-07$ \\
\hline Constant & $3.6356 * * *$ & 0.716 & 5.410 & 0.000 & \\
\hline
\end{tabular}

Reference category: Low risk 


\section{FIGURES}

Figure 1 - Final risk map and Mafia homicides 2012

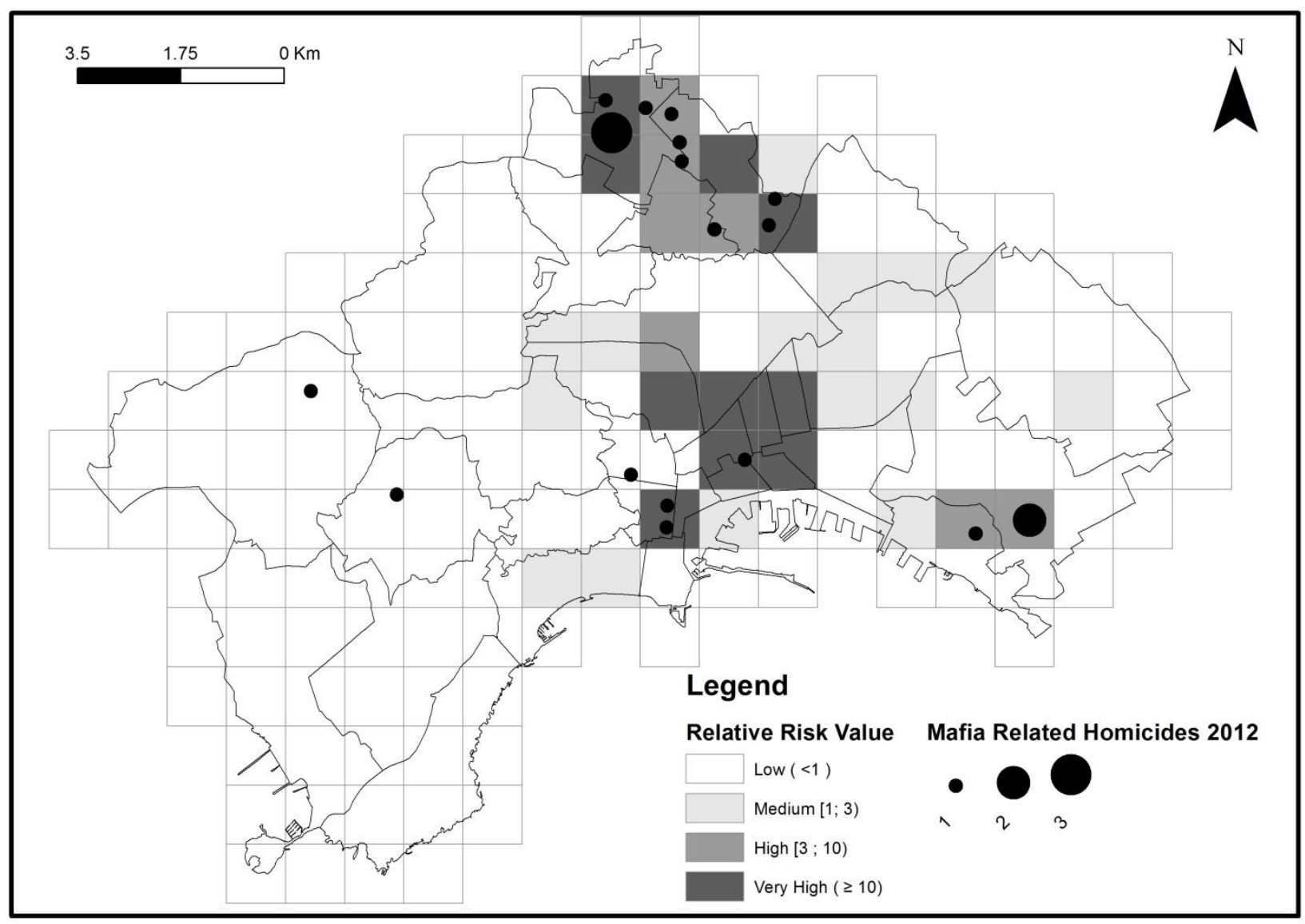


Figure 2 - Risk factors structure and homogeneity in the cells at very high and high risk
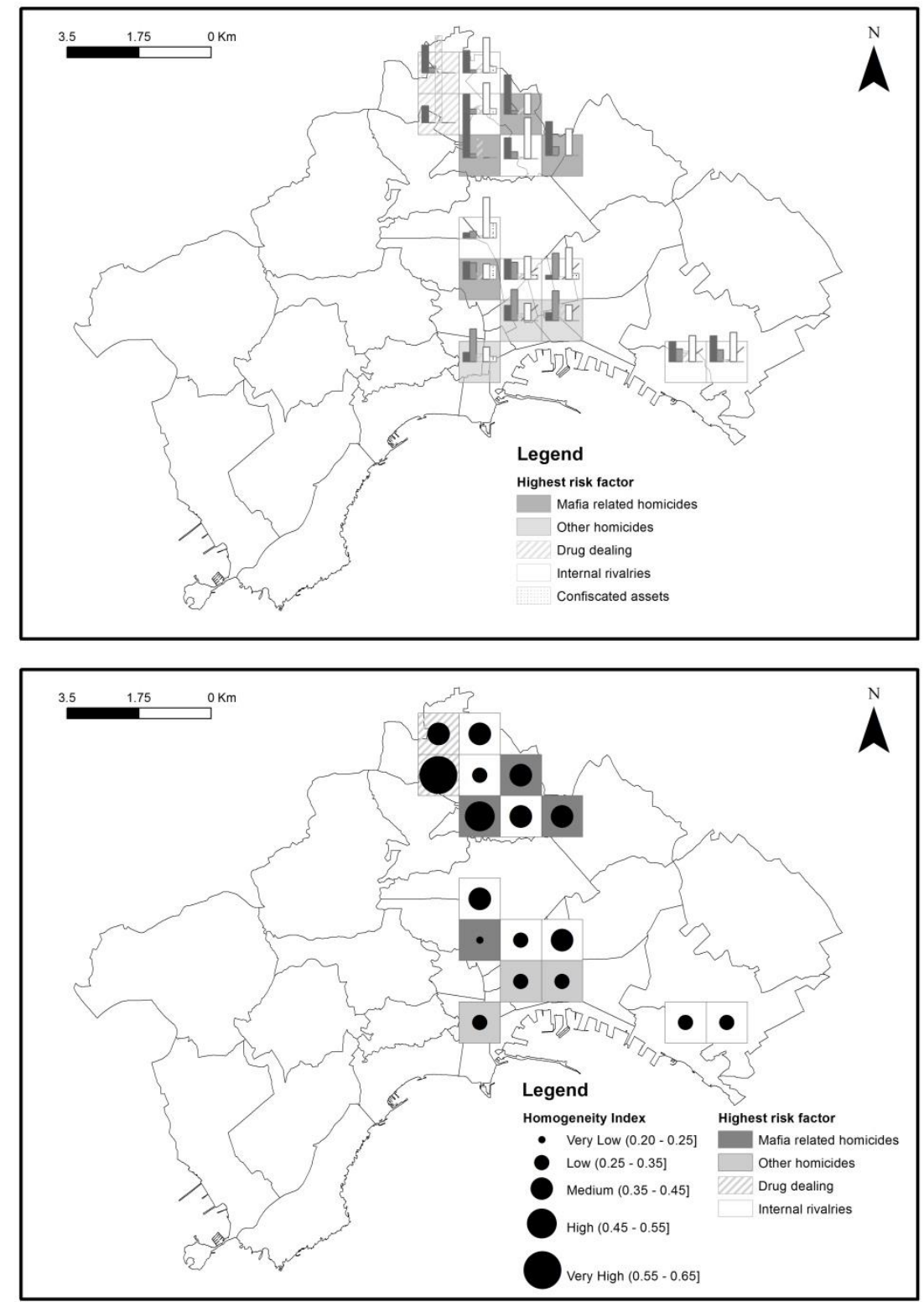


\section{End Notes}

${ }^{1}$ Authors' calculation on Italian Ministry of the Interior and Eurostat data.

${ }^{2}$ Authors' calculation on Italian Ministry of the Interior data.

${ }^{3}$ The study considers both attempted and completed mafia homicides. For a more detailed explanation of this choice see the Data section.

${ }^{4}$ Repetition of the analysis with a smaller cell size $(0.5 \times 0.5 \mathrm{~km})$ yielded equivalent results.

${ }^{5}$ The homogeneity index is calculated as the sum of the squared shares of the coefficients calculated for each risk factors in respect to their total sum. In the case of only one risk factor affecting the cell (perfect heterogeneity), it assumes value 1; in the case of a perfect homogeneity, it assumes value $1 / \mathrm{n}$ (where $\mathrm{n}$ is the number of risk factors). Homogeneity index $=\sum_{\mathrm{i}=1}^{\mathrm{n}}\left(\frac{\beta_{\mathrm{i}}}{\sum_{\mathrm{i}}^{\mathrm{n}} \beta_{\mathrm{i}}}\right)^{2}$

${ }^{6}$ The DIA reports provide information on each Camorra group in Naples, including a list of rival and allied groups, and the area over which each group exerts its control. Information on groups' turfs made it possible to identity the neighborhoods - and, as a consequence, the cells - in which one or more groups were active. Information on rivalries enabled identification of whether each Camorra group had conflicts with groups in the same neighborhood and/or groups in other areas of the city.

7 Project developed by Transcrime- UCSC with the financial support of the Italian Ministry of the Interior within the framework of the Programma Operativo Nazionale 2007-2013. 